\title{
PSYCHOPOETRY THERAPY MODEL TOWARDS ENHANCING COGNITIVE'S INSIGHT CLIENTS ON MENTAL DISORDERS IN PSYCHIATRIC HOSPITAL
}

\author{
(Model Terapi Psychopoetry terhadap Peningkatan Daya Tilik Diri Secara Kognitif pada \\ Klien Gangguan Jiwa di Rumah Sakit Jiwa)
}

\author{
Yeni Hendriani \\ Sekolah Tinggi Ilmu Kesehatan Rajawali \\ E-mail: hendrian1@yahoo.com
}

\begin{abstract}
ABSTRAK
Pendahuluan. Daya tilik diri secara kognitif merupakan aspek penting dalam penentuan diagnosis dan program terapi pada klien gangguan jiwa. Terapi psychopoetry sebagai intervensi modalitas berpedoman pada pembacaan dan penulisan puisi yang bersifat ekspresif dari perasaan klien. Tujuan penelitian untuk mengetahui pengaruh model terapi psychopoetry terhadap peningkatan daya tilik diri secara kognitif (komponen keyakinan diri) pada klien gangguan jiwa. Manfaat terapi psychopoetry sebagai sarana mengekspresikan perasaan klien yang tertekan dan dianggap berkontribusi terhadap masalah yang dihadapi. Metode. Metode penelitian menggunakan quasi experiment dengan rancangan non randomized pretest-posttest control group design. Hasil. Hasil penelitian terdapat perubahan bermakna dalam kelompok intervensi sebelum dan sesudah perlakuan, dan ketika dibandingkan dengan kelompok kontrol $(\mathrm{p}<0.05)$. Diskusi. Model terapi psychopoetry dapat digunakan dalam intervensi keperawatan di samping terapi lain yang selama ini telah dilaksanakan. Selain itu juga model ini mampu mengoptimalkan kemampuan membangun struktur kalimat dalam komunikasi dan merekomendasikan pengembangan kemampuan menulis secara produktif.
\end{abstract}

Kata kunci: Terapi psychopoetry, daya tilik diri, kognitif, modifikasi, ekspresif

\begin{abstract}
Introduction. Cognitive's insight is an important aspect in determining the diagnosis and treatment programs to clients with mental disorders. Psychopoetry therapy as an intervention modality based on the reading and writing of poetry those are expressive of the feelings of the client. Purpose of this study was to determine the effect of therapy models psychopoetry to measure themselves in the improvement of cognitive (self-assurance component) on the client's mental disorder. Benefits psychopoetry therapy as a means of expressing feeling depressed clients and are thought to contribute to the problem at hand. Method. The research method was used quasi-experimental research design with non-randomized pretest-posttest control group. Result. The results of this research were significant changes in the intervention group before and after treatment, and when compared with the control group $(p<0.05)$. Discussion. Psychopoetry therapy model can be used in addition to other therapeutic nursing interventions that have been implemented. This model is able to optimize the ability to build the structure of phrase in communication and recommended the development of writing skills productively.
\end{abstract}

Keywords: Psychopoetry therapy, insight, cognitive, modification, expressive

\section{INTRODUCTION}

According to the American Psychiatric Association (2012), mental disorder is a behavioral or psychological syndrome or pattern that occurs in an individual that reflects the major psychobiological dysfunction which is a reflection of clinically significant distress. Effective handling to mental disorderis through a combination of therapies, one of which is a therapeutic modality. Various types of modalities has been done in Indonesia include individual therapy, the environment (milleu therapy), somatic, cognitive, family, group, behavior and other therapies.

In US has been developed through a model of expressive therapy psychopoetry an attempt therapy effective in healing the mental and makes it easy to explore the client's feelings and arising thoughts from poetry stimulation. Psychopoetry is performed on the client in accordance with the tendencies of mental disorders such as irritable, sad, humiliated, disappointed, confused, hesitant, tense, depressed, wanting to be alone, and feel constantly guilty (Carroll, 2004). Therapeutic 
effect will gradually minimize those feelings through writing and reading poetry. Changes and developments are usually reflected in the poems themselves.

In Indonesia, psychopoetry therapy has not been widely recognized, because no doubt that poetry for most people to have a bad reputation, had nothing more than a bunch of strange words, expression of feelings of despair, full of exclamation points and had no any relevance with this life. This perspective is a misconception and needs to be fixed (Asyhadie, 2014). Carroll (2005) states that every person has an intuitive sense of where in general and poetry in particular sound can be a healing medium for individuals to have the experience of using words as soothing comfort. The use of the right words to articulate a traumatic experience can help the healing process quickly, either consciously or unconsciously. Specifically, excess psyichopoetry therapy model approach emphasizes the methods and media through training ideas in writing in the form of poetry.

So far the model psychopoetry therapeutic approach as one treatment modality is still a conceptual discourse so for the sake of implementation needs elaboration operationally through research.

\section{METHODS}

Quasi-experimental research designs has used non-equivalent study design (randomized) control group pretest and post test design (Stommel \& Wills, 2004). The populations in this study were mental disorder clients who were hospitalized in the Psychiatric Hospital of West Java Province. The sampling technique used in this research was purposive sampling methods. The calculation of sample size and study to examine differences in the sample were not independent on the design of pre-test and post-test. From the calculation of sample size obtained a total sample of 15 clients per group. Location of this research performed at the Psychiatric Hospital of West Java province, while a study conducted over 6 weeks.

Data collection in this study was done by using guided interviews (structured interview) guidelines based on a questionnaire that had been prepared previously through pre-test and post-test in the experimental group or the control group.

The research instrument consists of two types of instruments: 1) the form of therapeutic activity programs psychopoetry therapy, and 2) assessing therapeutic products in the form of insight scale, embraced the Beck Cognitive Insight Scale (BCIS) (2004) to test the validity of the results of the correlation product moment was 0.80 and Cronbach's alpha reliability test score coefficients was 0.81 . Components of confidence from BCIS consists of 6 items is about decision-making and resistance to feedback. Low scores on the subscales of selfbelief were considered normal.

Univariate analysis was obtained from counting descriptive statistics include mean, standard deviation, frequency and percentage distributions to describe the personal information of respondents. In analyzing the effect of the two variables are used the Wilcoxon Signed Ranks Test to know the difference in average rankings cognitive's insight in the treatment group and the control group $(\mathrm{p}<0.05)$ and Mann-Whitney test to compare the difference in average rank cognitive's insight between treatment groups with the control group $(\mathrm{p}<0.05)$.

\section{RESULTS}

The results from this table showed that before and after intervention, the median scores for insight (self confidence) in the intervention group was significantly different with $p$ value $=0.000$. The results from this table showed that before and after intervention, the median scores for insight (self confidence) in the control group was not significantly different with $p$ value $=0.498$.

The results from this table showed that before and after the intervention when compared intervention and control groups, there was a difference of $\mathrm{Z}$ scores for insight (self confidence) was -4.806 and $p$ value $=0.000$ were significantly different, respectively. 
Psychopoetry Therapy Model Towards Enhancing Cognitive's Insight Clients (Yeni Hendriani)

Table 1. The Differences Cognitive's Insight Before and After Treatment in The Intervention Group

\begin{tabular}{lccc}
\hline & $\mathbf{N}$ & $\begin{array}{c}\text { Median } \\
\text { (minimum-maximum) }\end{array}$ & $\mathbf{p}$ \\
\hline Before therapy & 17 & $\begin{array}{c}15.00 \\
(11.00-21.00)\end{array}$ & 0.000 \\
\cline { 1 - 2 } After therapy & 17 & $\begin{array}{c}10.00 \\
(4.00-17.00)\end{array}$ & \\
\hline
\end{tabular}

Table 2. The Differences Cognitive's Insight Before and After Treatment in The Control Group

\begin{tabular}{lccc}
\hline & $\mathbf{N}$ & $\begin{array}{c}\text { Median } \\
\text { (minimum-maximum) }\end{array}$ & $\mathbf{p}$ \\
\hline Before therapy & 15 & $\begin{array}{c}16.00 \\
(8.00-22.00)\end{array}$ & 0.498 \\
\cline { 1 - 3 } After therapy & 15 & $\begin{array}{c}17.00 \\
(10.00-22.00)\end{array}$ & \\
\hline
\end{tabular}

Table 3. The Comparison Cognitive's Insight Before and After Treatment in The Intervention and Control Groups

\begin{tabular}{lllll}
\hline & Group & N & Z & p \\
\hline Intervention & 17 & & -4.806 & 0.000 \\
\hline Control & 15 & & \\
\hline
\end{tabular}

\section{DISCUSSION}

Clients with mental disorders experience a change in their cognitive so as to affect the volition, emotional (affective), and psychomotor as a result of an unpleasant experience, so often the client will make the repression process of traumatic memory. It will affect the ability to remembering and thinking ability client. But in general, the client still has the intuitive feeling through sound, and in particular through the poetry to express it in monologue way. This is common to occur because the client considers it as a soothing comfort.

Specifically excess psychopoetry therapy model approach suggests the use of the right words to articulate a traumatic experience that happen it, then to help the healing process quickly. The emphasis through stimulation with methods and media literacy training and ideas in writing in the form of poetry or prose that has not be disclosed.

Psychopoetry therapy program divided into two terms, namely terms poetry readings and accompanied by discussions in describing the feelings contained in both poetry and works of the great poets of his or her own. Each term is divided into several sessions.

Poetry session of the great poet's work is the beginning of therapy, of course without neglecting the principle of mutual trust relationship to the therapist and other group members. As in the selection of the poems that will be read must have a metre in the sense that poetry has an emphasis on provoking and embedding of robust memories that has an influence on the brain, both with regard to images and sound. Metre poems tend to be patterned so that the client will recall the poem becomes easier.

The effect of reading a poem will increase brain activity and the ability of self-reflection so empowering individuals to enter memory-though daunting in identifying himself with the state of the soul of the poet who is also experienced by himself. The similarity of the fate of the spirit of life can restore clients in receiving their condition. 
Based on the observation, after four sessions of poetry readings and providing identification that he read the meaning of the poem, the majority $(80 \%)$ of clients in the treatment group showed liveliness, appreciation and good suitability affective.

After reading the poem, follow by 4 sessions of writing poetry. In this session, the theme is determined by the therapist, and the client is freely to determine its own title. Beginning with the work of therapist was writing poetry, followed by the clients. In this session, the client is more effective role in exploring the ability to express themselves and create something, but it also felt more whole.

In literary reviews Asyhadie (2014) has analyzed those poems by 37 of 17 respondents that poetry as a means of self-expression and learning are reviewing each respondent's ability to find, filter, unite and write down observations, thoughts, emotions and personal experience, and then review the ability to use language tools. The success or failure of the respondent relies on the success or failure to execute in such matters.

Further, Asyhadie reviewed that the respondents in this study largely has known poems are able to show a fairly good understanding of the logic of the clause and between clauses. Clauses that they have created with the purpose of control and poetic elements (metaphor) are quite good. This is evidenced when each respondent makes two of poetry, they were able to put together a predisposition to tie verse after verse and managed to close their poetry with logically. Although it was not many take advantage of the poetic elements but only to seek the presence of a rhythm through beheading clause and typography, but overall still had systematically, paragraph transitions, as well as the logical closure.

The terms of the content of poetry, literary Asyhadie revealed nearly $100 \%$ of the poetry of the respondents did leap on some temple displacement by trying to remember directly on the outside of clients condition. The clients had not explored deeper memory of the experience itself. As an example of the LM client poem below;
"Kutermangu dalam duduk

Mengingat kembali kejadian yang tlah lalu

Kucoba sekuat tenaga

Kucoba... dan coba terus

Sampai pada titik sadar

Betulkah semua ini

Sampai akhirnya kuada disini

Ditempat ini

Tapi... kujumpai teman-teman"

Paragraph transfer in the line from the end of the first verse of "I tried... and tried to keep" to the next paragraph showed there is an event that she passed or covered it because there is a barrier of her to dig deeper into that memories, which consciously or unconsciously. She was a in the long term memory through the process of repression. Furthermore, Asyhadie said that the "key" can be opened if the client voluntarily wants to open it. A writer Czechoslovakia, Kundera strengthen the above opinion that writing poetry is an attempt to fight forgotten.

\section{CONCLUSIONS}

The therapy models psychopoetry can to improve of cognitive (self-assurance component) on the client's mental disorder. Psychopoetry therapy as a means of expressing feeling depressed clients and are thought to contribute to the problem at hand.

\section{RECOMMENDATION}

Psychopoetry therapy model can be used in addition to other therapeutic nursing interventions that have been implemented. This model is able to optimize the ability to build the structure of phrase in communication and recommended the development of writing skills productively.

\section{REFERENCE}

Asyhadie, N. (2014). Kecerdasan puitik sebagai fenomena kecerdasan matematika. Jakarta: Kushalamula 
Psychopoetry Therapy Model Towards Enhancing Cognitive's Insight Clients (Yeni Hendriani)

American Psychiatric Association. (2012). Definition of a mental disorder.

Carroll, R. The Healing Power of Poetry. Retrieved from http://www.dsm5. org/proposedrevision/Pages/ proposedrevision . aspx? $\mathrm{rid}=465$ (2005). Los Angeles. 